\title{
The Influence of The Environment of Pesantren And Friends on Learning Outcomes
}

\author{
Mohammad Miftahusyai'an ${ }^{1, *}$, Yussi Rusdiana², Galih Puji Mulyoto ${ }^{3}$ \\ 1,2,3 Universitas Islam Negeri Maulana Malik Ibrahim Malang, Indonesia \\ *Corresponding author.Email: pak.miftahusyaian@gmail.com
}

\begin{abstract}
This research was conducted aiming to determine the effect of the environment of boarding schools and peers on the learning outcomes of students of class XI IPS MA 1 Annuqayah daughter of Sumenep, both partially and simultaneously. With this research, it is expected that teachers and the school will know how much influence the environment of boarding schools and peers on student learning outcomes. Research is a descriptive study using a quantitative approach. The data collection method used was a questionnaire method (questionnaire). The study population was all students of class XI IPS MA 1 Annuqayah daughter with a sample of 178 students. Analysis of the data used is descriptive statistical analysis and multiple linear regression. The results of this study indicate that: (1) The environment of Islamic boarding schools has a significant positive effect on student learning outcomes in XI IPS MA 1 Annuqaya $h$ Putri shown by $t$ hitung2,225>t_(table) 1,972. (2) The peers had a significant positive effect on the learning outcomes of students of class XI IPS MA 1 Annuqayah Putri, which was shown by t_hitung2,040>t (table) 1,972. (3) The environment of Islamic boarding schools and peers has a significant positive effect on the learning outcomes of students of class XI IPS MA 1 Annuqayah Putri, indicated by t_hitung5,708>t_(table) 3.05.
\end{abstract}

Keywords: Boarding School Environment, Peers, Learning Outcomes.

\section{INTRODUCTION}

Bratanata ets1 stated that "Education is a deliberate effort to be held either directly or indirectly to help children in their development reach their godhood [1]. The Education of a country depends on the quality of human resources (HR) in it. The quality of a country's human resources can be seen from the learning outcomes achieved. Learning outcomes are changes in behavior that occur in a person that can be measured and observed in knowledge, attitudes, and skills. The changes can be interpreted as an increase or development that occurs in humans as a result of learning from not knowing to know [2]. The results of learning obtained every student be read, this is due to different characteristics of each student, and there are several factors that influence student learning outcomes.

According to Slameto, there are two factors that affect student learning outcomes, namely, internal factors and external factors. Internal factors are factors that come from a person or expertise that comes from students, such as motivation, interests, talents, physical, and intelligence conditions. At the same time, external factors come from outside a person's spines, such as curriculum, facilities, environment, family economic status, and teaching. These two factors are interrelated to create the right learning conditions and get learning outcomes as expected. One of the external factors that significantly influence student learning outcomes is environmental factors. According to Munib, "the environment is generally defined as a unity with all objects, forces, conditions, and living things, including humans and their behavior that affects the continuity of life and the welfare of humans and other living creatures"[3].

The environment to be discussed here is the boarding school environment. According to Manfred Ziemek, the pesantren is a dormitory for students to live and study with teachers or Kiai (clerics or clerics) regarding lessons covering various Islamic knowledge[4]. In Islam, education is considered very important. Muslims have the responsibility to study as instructed in the QS. Al-Alaq: 7, QS. Yusuf: 76, QS. An-Nahl: 70 and in Islam learning is considered as 
worship to Allah SWT. Islamic Education in Indonesia has a long history. Before the Dutch introduced modern Education in the 19th century, Education in Indonesia was Islamic Education for a very long period of time. These Islamic education institutions include the surau, majlis tackle, pesantren, and madrasah. These institutions have been accepted in society and have their own principles that are very strong in the life of the Indonesian nation. In its development, Islamic Education has a very strategic place, connected with the ideals and hopes of national development, namely shaping the whole Indonesian people with the power of faith and piety. This is the reason Islamic Education is easily included in national development efforts [5]. In line with the demands of the times, Islamic Education has also developed like the development of Islamic boarding schools. The first pesantren was the Tebuireng pesantren (1916), followed by other pesantren [6].

In this study, researchers took place in Sumenep, to be precise at the MA 1 Annuqayah Putri school, where students were required to live in Islamic boarding schools. Students who also have the status of santri at the Islamic boarding school have a different environment from students who are not santri or students who do not live in the Islamic boarding school. In the Islamic boarding school environment, they carry out activities or activities that are a little denser than students who do not live in the Islamic boarding school because of all the rules and discipline such as learning activities carried out at school.

Students who live in boarding schools generally have more independence than students who live with their families. Students who live in Islamic boarding schools or commonly known as santri, are taught to do their daily activities without the help of their parents. And students are taught to be able to manage their daily time. Because in the Islamic boarding school, there are activities that are denser than at home. As is the case in the Annuqayah Islamic boarding school, where several regulations are stipulated, such as study hours, diniyah hours, and compulsory congregational prayer. Students who are also santri are required to follow the rules set out in the Islamic boarding school.

Students in Annuqayah spend their morning to evening informal school, where they spend a lot of time and exchange ideas with their peers. Peer groups are groups of people who have the same age and have the same status with whom generally people relate or hang out [7]. Therefore, it can be said that more students are with their peers both at school and outside of school. Peers have a significant influence on student behavior and student learning processes, especially students who live in Islamic boarding schools, where a lot of their daily lives are spent with their peers. Therefore, peers are also an external factor in Education that can affect student learning outcomes.
Based on the background of the problems described above, the researcher is interested in examining this problem under the title "The influence of the Islamic boarding school environment and peer relationships on student learning outcomes of class XI IPS MA1 Annuqayah Pi Sumenep-Madura".

\section{RESEARCH METHODS}

This study uses a quantitative approach with descriptive research type to describe the effect of the variables of the Islamic boarding school environment and peer environment on learning outcomes. Multiple linear regression analysis was used to determine the impact of the Islamic boarding school environment and peers on student learning outcomes in class XI IPS MA 1 Annuqay ah Putri Sumenep. The population in this study were all students of class XI IPS MA 1 Annuqayah Putri Sumenep as many as 317 with a total sample of 178 students who were taken using the Slovin formula. In this study, the researcher determined the selection using a stratified random sampling technique because the number of students in each class was not the same.

The data collection technique used was a questionnaire for environmental and peer variables and documentation for the student learning outcomes variables. The test of the ecological variable instrument of the boarding school was 18 items, and the peer variable was 14 . The validity test of the environmental device of the boarding school and peers was using the product-moment correlation formula. And to test the reliability using Cronbach's alpha formula. The results of the validity test of Islamic boarding school environmental variables using 18 items obtained three items of failure, and peer variables using 14 items received four items of failure. So that in the Islamic boarding school environmental variable, there are 15 valid items, and in the peer variable, there are ten valid items. In the results of the reliability test, the two variables were declared valid with the alpha value of the Pondok Pesantren environmental variable of 0.786 and the peer variable of 0.641 .

The data analysis technique used descriptive statistical analysis techniques to describe the environmental variables of the boarding school and peers. And the linear regression test is preceded by the classical assumptions of normality, multicollinearity test, linearity test, and heteroscedasticity test. And hypothesis testing is the T-test (partial) and F test (simultaneous).

\section{RESULT AND DISCUSSION 3.1 RESULT}

Environmental variable data for Islamic boarding schools were obtained from a questionnaire with 15 
question. Each question is given five alternative answers, and each answer is given a score. The items were given to respondents, amounting to 187 students. From the questions presented, the highest score and lowest score were found. From the 15 questions provided, the highest score was 75 (15 x 5), and the lowest score was $15(15 \times 1)$. So that from the formula, the length of the interval class from the environmental variable of the boarding school is 12 .

Table 1. Frequency Distribution of Islamic Boarding School Environment

\begin{tabular}{|c|c|c|c|c|}
\hline \multirow{2}{*}{ Ath } & \multirow{2}{*}{ Interval } & \multirow{2}{*}{ Aritaris } & \multicolumn{2}{|c|}{ Frequency } \\
\hline & & & $\mathrm{F}$ & $\%$ \\
\hline 1 & $15-27$ & Very bad & 0 & $0 \%$ \\
\hline 2 & $28-39$ & Bad & 0 & $0 \%$ \\
\hline 3 & $40-51$ & Moderate & 5 & $2,8 \%$ \\
\hline 4 & $52-63$ & Well & 96 & $53, \%$ \\
\hline 5 & $64-75$ & Very good & 77 & $43, \%$ \\
\hline \multicolumn{3}{|c|}{ Total } & 78 & $100 \%$ \\
\hline
\end{tabular}

Based on table 1. The frequency distribution of the peer environment variable consists of 5 interval classes, with class lengths having a score range of 12 . Interval classes $15-27$ with very bad criteria are 0 students $(0 \%)$. The class interval 28-39 with bad criteria is 0 students $(0 \%)$. Interval class $40-51$ with moderate criteria is 5 students $(2.8 \%)$. Interval class 52-62 with good criteria is 96 students (53.9\%). Interval class $63-73$ with very good criteria is 77 students $(43.2 \%)$. Thus, it can be concluded that the boarding school environment is in the good category.

Peer variable data were also obtained from a questionnaire with 10 questions. Each question is given 5 alternative answers and each answer is given a score. Questions were given to respondents, amounting to 187 students. From the questions given, it was found the highest score and the lowest score. From the 10 questions provided, the highest score was $50(10 \times 5)$ and the lowest score was $10(10 \times 1)$. So that from the calculation of the formula, it is obtained that the interval class length of the peer variable is 8 . It can be seen the frequency distribution as follows.

Based on table 2, the frequency distribution of the peer variable consists of 5 interval classes, with class lengths having a score range of 8 . The 10-18 class intervals with terrible criteria are 0 students $(0 \%)$. Interval class 19-26 with flawed standards is three students (1.7\%). Interval class 27-35 with reasonable measures is 26 students $(14.6 \%)$. The $36-48$ interval class with the right criteria is as many as 85 students (47.7\%). Interval class 44-51 with perfect standards were 64 students (35.9\%). Thus, it can be concluded that peer interaction is in a suitable category.

Table 2. Peer Frequency Distribution

\begin{tabular}{|c|c|c|c|c|}
\hline \multirow{2}{*}{ No } & Interval & \multirow{2}{*}{ Criteria } & \multicolumn{2}{|c|}{ Frequency } \\
\cline { 4 - 5 } & Score & & $F$ & $\%$ \\
\hline 1 & $10-18$ & Very bad & 0 & $0 \%$ \\
\hline 2 & $19-26$ & Bad & 3 & $1,7 \%$ \\
\hline 3 & $27-35$ & Moderate & 26 & $14,6 \%$ \\
\hline 4 & $36-43$ & Well & 85 & $47,7 \%$ \\
\hline 5 & $44-51$ & Very good & 64 & $35,9 \%$ \\
\hline \multicolumn{3}{|c|}{ Jumlah } & 178 & $100 \%$ \\
\hline
\end{tabular}

The acquisition of learning outcomes in this study was measured by the indicator of the odd semester test scores of class XI IPS MA 1 Annuqayah Putri. From the bizarre semester test scores, the highest and lowest scores were obtained, which were grouped according to the MA 1 Annuqayah Putri assessment criteria, which were based on the KKM (Minimum Completeness Criteria) to determine the learning outcomes of class XI students. The KKM score determined by the school is 75. The student learning outcomes are presented in table 3.

Table 3. Frequency Distribution of Learning Outcomes

\begin{tabular}{|c|c|c|l|l|}
\hline \multirow{2}{*}{ No } & Interval & \multirow{2}{*}{ Criteria } & \multicolumn{2}{|c|}{ Frequency } \\
\cline { 4 - 5 } & Score & & $F$ & \multicolumn{1}{|c|}{$\%$} \\
\hline 1 & Under 75 & Very bad & 6 & $3,3 \%$ \\
\hline 2 & $75-83$ & Bad & 114 & $64 \%$ \\
\hline 3 & $84-92$ & Moderate & 29 & $16,3 \%$ \\
\hline 4 & $93-100$ & Well & 29 & $16,3 \%$ \\
\hline \multicolumn{3}{|c|}{ Total } & 100 & $100 \%$ \\
\hline
\end{tabular}

Based on table 3. the peer variable frequency distribution consists of 5 interval classes, based on the KKM value (Minimum Completion Criteria) MA 1 Annuqayah Putri. Interval class Below 75 with unfavorable criteria is as many as six students (3.3\%). The class interval 75-83 with sufficient measures is 114 students (64\%). The 84-92 interval class with the right criteria is 29 students $(16.3 \%)$. Interval class $93-100$ with perfect standards were 29 students (16.3\%). Thus, in general, it can be stated that the learning outcomes of class XI IPS MA 1 Annuqayah Putri can be categorized as sufficient. What can be seen from the number of students as much as 64\% got a score between 84-92.

In this study, the classical assumption test was carried out, namely, the normality test using the Kolmogorov-Smirnov significance because the 
respondents in the survey were more than 50 people. The following are the results of the analysis of the normality test with the Kolmogorov-Smirnov importance with the help of SPPS 16.00 for window.

Table 4. Kolmogrov-Smirnov Normality Test

One-Sample Kolmogorov-Smirnov Test

\begin{tabular}{|ll|c|}
\hline & $\begin{array}{c}\text { Unstandardized } \\
\text { Residual }\end{array}$ \\
\hline $\mathrm{N}$ & 178 \\
Normal Parameters & Mean & .0000000 \\
& Std. Deviation & 3.30160458 \\
Most Extreme & Absolute & .064 \\
Differences & Positive & .064 \\
& Negative & -.056 \\
Kolmogorov-Smirnov Z & .856 \\
Asymp. Sig. (2-tailed) & .456 \\
\hline
\end{tabular}

a. Test distribution is Normal.

From table 4, the Kolmogorov-Smirnov Sig. Amounting to 0.456 , which means greater than 0.05 so that from the data, it can be concluded that the residual data is typically distributed. Second, multicollinearity test, following the multicollinearity test results with the help of SPPS 16.00 for windows.

Table 5. Multicollinearity Test

Coefficients $^{a}$

\begin{tabular}{|c|c|c|c|c|c|c|c|}
\hline \multirow[t]{2}{*}{ Model } & \multicolumn{2}{|c|}{$\begin{array}{c}\text { Unstandardized } \\
\text { Coefficients }\end{array}$} & $\begin{array}{c}\text { Standar } \\
\text { zed } \\
\text { Coeffici } \\
\text { ts }\end{array}$ & \multirow[t]{2}{*}{ 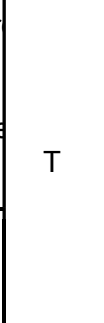 } & \multirow[t]{2}{*}{ Sig. } & \multicolumn{2}{|c|}{$\begin{array}{l}\text { Collinearity } \\
\text { Statistics }\end{array}$} \\
\hline & B & Std. Errd & Beta & & & e & VIF \\
\hline 1(Constant) & 66.628 & 5.027 & & 13.253 & 000 & & \\
\hline $\begin{array}{l}\text { L.Pondok } \\
\text { Pesantren }\end{array}$ & .160 & .072 & .166 & 2.225 & 027 & 359 & $1.04\}$ \\
\hline $\begin{array}{l}\text { Friends of the } \\
\text { same age }\end{array}$ & .165 & .081 & .153 & 2.040 & 043 & 359 & 1.04 \\
\hline
\end{tabular}

a. Dependent Variable: Learning outcomes

As in table 5 above, it can be seen from the multicollinearity test results that the VIF value for the environmental variable of the Islamic boarding school is 1.043 , and the tolerance value is 0.959 . For the peer variable, the VIP value is 1.043 , and the tolerance value is 0.959 . So from the data above, it can be concluded that there is no high correlation between the environmental variables of the boarding school and peers so that the relationship between the two independent variables is not disturbed. Third, the linearity test in this study was conducted using SPSS 16.00 for windows and was carried out by comparing means.

Table 6. Linieritas Test

\begin{tabular}{|c|c|c|c|}
\hline Variabel & Df & Sig & A \\
\hline $\mathrm{X} 1 \stackrel{\mathrm{Y}}{\longrightarrow}$ & 26 & 0,086 & 0,005 \\
\hline $\mathrm{X} 2 \longrightarrow \mathrm{Y}$ & 23 & 0,336 & 0,005 \\
\hline
\end{tabular}

It can be seen that the sig value of the environmental variable of Islamic boarding schools is 0.086 , and the sig value of the peer variable is 0.336 , which is greater than 0.05 . So from the data above, it can be concluded that the environmental variables of Islamic boarding schools and peers have a linear relationship with the dependent variable, namely learning outcomes, and regression analysis can be carried out. Fourth, the Heteroscedasticity Test in this study, the Heteroscedasticity test, was carried out using the Scatterplot test with SPSS 16.00 for windows.

\section{Scatterplot}

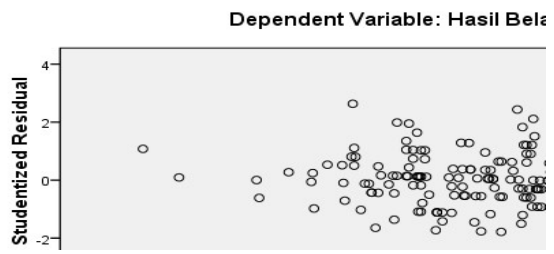

Figure 1. Heterokedastisitas Scatterplot Test

From Figure 1. It can be seen that the distribution of data points is above and below or around zero, and the distribution of data points also does not form a pattern. So that from the data above, there is no variance inequality of the research variable residuals.

After the classical assumption test was carried out, the next step was multiple linear regression analysis. To find out how strong the influence of each independent variable (X) on the dependent variable, namely student learning outcomes $(\mathrm{Y})$. This study is to determine how much power the environment of the boarding school and peers on learning outcomes. Following are the results of multiple linear tests:

Based on table 7 of the calculation results, it is obtained a multiple linear regression equation: $\mathrm{Y}=$ $66.628+(0.160 \mathrm{X} 1)+(0.165 \mathrm{X} 2)+$ e. Constans 66.628 
means that learning outcomes will be constant at 66.628 if not influenced by the environmental variables of Islamic boarding schools and peers. Coefficients b1 0.160 boarding school environment (X1) affects learning outcomes (Y) by 0.160 or has a positive effect, which means that if the boarding school environmental variable $(\mathrm{X} 1)$ has increased/decreased by $1 \%$, the learning outcomes (Y) will increase/decrease 0.160 . Coefficients b2 0.165 peers (X2) affect learning outcomes (Y) by 0.165 or have a positive effect, which means that if the peer variable (X2) only increases/decreases by $1 \%$, learning outcomes (Y) will increase/decrease 0.165 .

Table 7 . Linear Regression Test Results

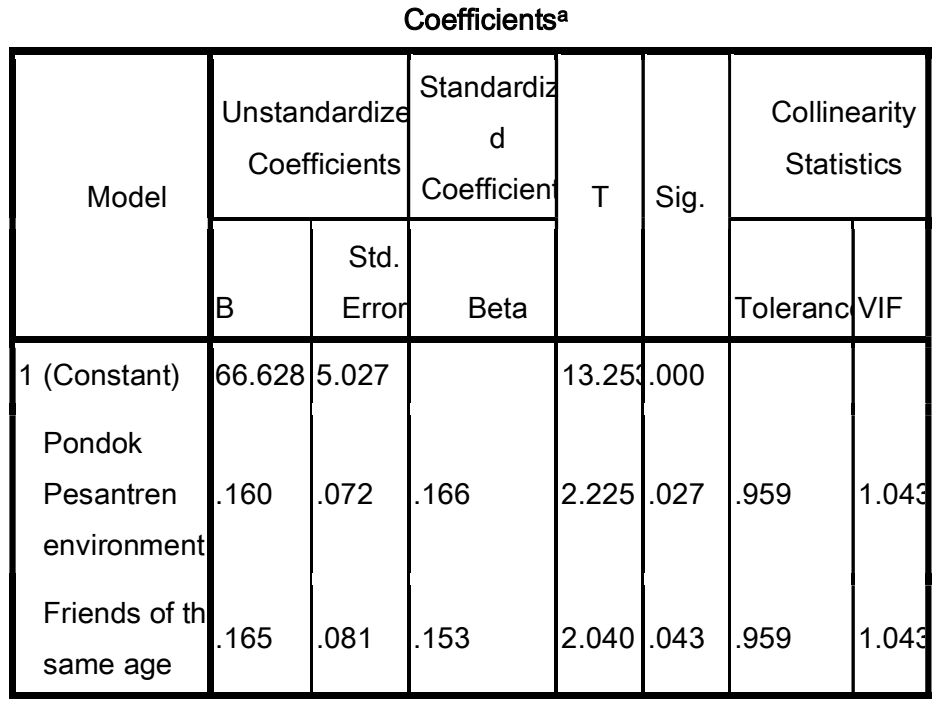

a. Dependent Variable: Learning outcomes

To find out how much the independent variable is used in the regression test to explain the dependent variable, namely learning outcomes. The coefficient of determination test was carried out with the help of SPSS 16.0 for windows. The table 3 is the results of the determination coefficient test.

Table 8. The coefficient of determination

Model Summary

\begin{tabular}{|c|c|l|l|c|}
\hline Model & $R$ & R Square & $\begin{array}{c}\text { Adjusted R } \\
\text { Square }\end{array}$ & $\begin{array}{c}\text { Std. Error of } \\
\text { the Estimate }\end{array}$ \\
\hline 1 & $.247^{\mathrm{a}}$ & .061 & .051 & 6.911 \\
\hline
\end{tabular}

a. Predictors: (Constant), Friends of the same age, Pondok Pesantren environment

b. Dependen Variabel Learning outcomes
From table 8 , it can be seen that $\mathrm{r}$ is 0.061 , thus it can be said that there is a simultaneous correlation between the environmental variables of the boarding school and peer $n$ themes on learning outcomes and the correlation between the two independent variables on the dependent variable is weak because the r-value is 0.061 close to 0 . The $\mathrm{R}$ square value of 0.061 means that the learning outcomes can be explained by the pesantren and peers' pond ok environment as much as $6.1 \%$, and the remaining $93.9 \%$ is explained by other variables.

Hypothesis testing in this study used the T-test and $\mathrm{F}$ test. A partial test of environmental variables at Islamic boarding schools was carried out using SPPS 16.0 for windows. The test results are presented in table 9.

Table 9 . Partial Test of Islamic Boarding School Environment

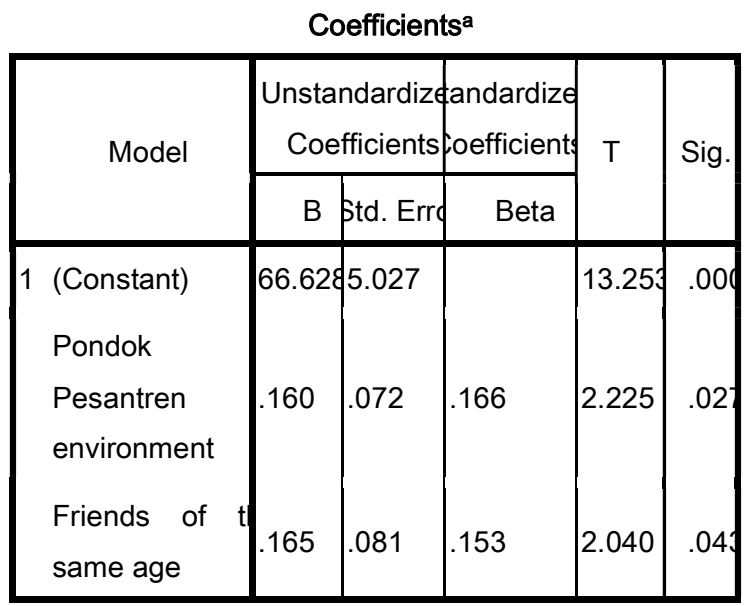

a. Dependent Variable: Learning outcomes

To determine whether there is an influence of the Islamic boarding school environment on student learning outcomes, it can be seen using two ways: (a) Comparing the value of $t$ count with $t$ table. From the table above, it is obtained the value of $t$ count $=2.225$ and $t$ table with a level of $5 \%$ obtained a value of 1.972 . The comparison between the two results in: $t$ _count $>t$ (table), namely 2,225>1,972. (b) Comparing Sis values. With $\alpha$. From the table above, the Sig value is obtained. $\neg=0.027$ and $\alpha=0.05$. The comparison between the two results in Sig. $<\alpha$, namely $0.027<0.05$. Thus, looking at the above comparison shows that the environmental variables of the Islamic boarding school partially have an influence between the boarding school environment on social studies learning outcomes in class XI MA 1 Annuqayah Putri.

The peer variable T-test was performed using SPPS 16.0 for windows. The test results are presented in the table 10 . 
Tabel 10 Peer Partial Test

\begin{tabular}{|c|c|c|c|c|c|}
\hline \multicolumn{6}{|c|}{ Coefficients ${ }^{a}$} \\
\hline \multirow{4}{*}{ Model } & \multirow{2}{*}{\multicolumn{2}{|c|}{ Unstandardized }} & \multirow{3}{*}{$\begin{array}{l}\text { Standardi } \\
\mathrm{d} \\
\text { Coefficien }\end{array}$} & \multirow{4}{*}{$\mathrm{T}$} & \multirow{4}{*}{ Sig. } \\
\hline & & & & & \\
\hline & \multicolumn{2}{|c|}{ Coefficients } & & & \\
\hline & $B$ & Std. Errc & Beta & & \\
\hline 1 (Constant) & 66.628 & 5.027 & & 13.25 & 4.000 \\
\hline \multirow{4}{*}{$\begin{array}{l}\text { Pondok } \\
\text { Pesantren } \\
\text { environment } \\
\text { Friends of the } \\
\text { same age }\end{array}$} & .160 & .072 & .166 & 2.22 & .027 \\
\hline & & & & & \\
\hline & & & & & \\
\hline & .165 & .081 & .153 & 2.04 & d.043 \\
\hline
\end{tabular}

To determine whether there is an influence of the boarding school environment on student learning outcomes, it is seen using two ways, namely: (a) Comparing the value of $t$ count with $t$ table. From the table above, the value of $t$ count $=2.040$ and $t$ table el with a level of $5 \%$ obtained a value of 1.972 . The comparison between the two a results: t_count $>\mathrm{t}$ (table), namely 2.040> 1.972. (b) Comparing the Sig. With $\alpha$. From the table above, the Sig value is obtained. $\neg=0.043$ and $\alpha=0.05$. The comparison between the two results in Sig. $<\alpha$, namely $0.043<0.05$. Thus, seeing the above comparison shows that the peer variable partially has an influence between peers on social studies learning outcomes in class XI MA 1 Annuqayah Putri.

The next hypothesis testing is the $\mathrm{F}$ test (Simultaneous) to determine the effect of the Islamic boarding school environment and peers on social studies learning outcomes using SPPS 16.0 for windows. Based on the calculation, the value of $\mathrm{F}$ hitung $=5.708$ and the value of Sig. $=0.004$. To determine the effect of the Islamic boarding school environment and peers on social studies learning outcomes, it is done in 2 ways, namely: (a) Comparing the value of $F$ count with $F$ table. From the table above, it is obtained that the value of $\mathrm{F}$ count $=5.708$ and $\mathrm{F}$ table with a level of $5 \%$ obtained a value of 3.04. The comparison between the two results in: $t$ hitung $>t$ _ (table), namely 5.708 $>3.05$. (a) Comparing the Sig. With $\alpha$. From the table above, the Sig. $\neg=0.004$ and the value of $\alpha=0.05$. The comparison between the two results in Sig. $<\alpha$, namely $0.004<0.05$. Thus, looking at the comparison above shows that there are significant boarding school environment and peers seca a concurrent (simultaneous) against the results of social studies class XI MA 1 Annuqayah, Putri.

\subsection{Discussion}

Based on the analysis of research data obtained from the field, there are several results. The first is that there is a significant influence between the boarding school environment on the learning outcomes of class XI IPS MA 1 Annuqayah Putri. Second, there is a substantial influence between peers on the learning outcomes of class XI IPS MA 1 Annuqayah Putri. Third, there is a significant influence between the Islamic boarding school environment and peers on the learning outcomes of class XI IPS MA 1 Annuqayah Putri.

The results of the first study are in line with Slameto's opinion, which states that student learning outcomes are influenced by two factors, namely, internal factors and external factors [8], The internal factors in question are factors that can affect student learning outcomes that come from within students. In contrast, external factors are factors that affect student learning outcomes that come from outside the student. In this case, the boarding school environment is an external environment that affects student learning outcomes. A student who lives in a boarding school environment will be affected by the atmosphere in the boarding school, including in terms of learning. This can be seen from the answers to the questionnaire distributed to class XI IPS MA 1 Annuqayah Putri. There were $38.8 \%$ of students answered that the boarding school environment motivated students to study hard.

Furthermore, the results of the first study also agree with Munib's opinion, according to him that the environment is generally defined as a unity with all objects, forces, conditions, and living things, including humans that affect the continuity of life and welfare of humans and other living things [3] In a boarding school, there is a Kiai who is in charge of teaching the students. A Kiai in a boarding school is the students' central role model; this is because many Kiai masters the knowledge. From the answers to the class XI IPS MA 1 Annuqayah Putri questionnaire, $48.9 \%$ of respondents answered that the Kiai motivated students to study hard. The questionnaire results show that Kiai can become a motivator for students to learn more actively to improve the learning outcomes obtained.

Also, the results of the first study are in line with the opinion of Zulrikza Iskandar, who explained that there is a field theory that explains human behavior that occurs as a result of the forces that work when humans interact with their environment. One of the troops referred to his power that is not human, such as rules, norms, customs, etc. The regulations in an environment will affect a person's behavior in it [9]. Judging from the answers to the questionnaire described earlier, the boarding school environment occupied by class XI MA 1 Annuqayah Putri students has several rules and activities required of all students, such as study hours, 
diniyah, and other activities. Some of these rules will become a good habit for students and will also impact the learning outcomes of students in traditional schools because students are more disciplined in terms of learning.

The results of the second study regarding the influence of peers on learning outcomes are in line with the opinions of several figures, as stated by Blazevic, who said that peers are a social group consisting of people of similar age, education, or social status [10]. Despite explained that peer groups in adolescence are more based on friendly relationships [11]. Jonh W. Santrock revealed several contributions of friendship to peers, one of which is togetherness [12]. The time spent at school provides excellent opportunities for students to socialize and interact with peers at school. This togetherness gives a sense of comfort, which then cares and supports each other in terms of lessons. As previously explained, the questionnaire results distributed to class XI IPS MA 1 Annuqayah Putri answered that students do a lot of things with their peers, and students often do assignments with peers at school. Therefore, if peers have a good influence, it will have a good impact, and vice versa; if peers have a terrible power, it will hurt students.

MA 1 Annuuqayah Putri is a school that requires students to live in Islamic boarding schools. For students in Islamic boarding schools, the environment and the people around them are essential and influential for students and their learning. In addition to students having to pay attention to the comfort of the environment they are in, students must also have good relationships with the people around them. The results of a questionnaire from class XI IPS MA 1 Annuqayah Putri, as many as $47.2 \%$ of respondents answered that students felt comfortable studying in a boarding school environment. As many as $61.8 \%$ of respondents answered that students enjoyed learning with peers. Therefore, students will get good learning outcomes. The same results were shown by the research of [13] there is a significant influence between the school environment on students' learning outcomes.

Good learning outcomes can be achieved by studious students. In terms of learning, students need encouragement and enthusiasm in carrying it out. The primary motivation for a santri is the motivation of a Kiai. For students, Kiai is a role model in seeking knowledge. Apart from inspiration from the Kiai, a student also needs enthusiasm from his closest people, such as peers who spend a lot of time together in their daily lives. The relationship between the two in influencing student learning outcomes can be seen from the results of student questionnaires; as many as $48 \%$ of students answered that Kiai motivates students in learning. As many as $48.3 \%$ of students responded that peers often encourage students when students are lazy to learn.

From the explanation of the pesantren and peer group environment above, it can be concluded that both have a significant relationship in influencing student learning outcomes. Suppose a student occupies an excellent and supportive environment in terms of learning and has good relationships with people in that environment. In that case, a student will feel more comfortable learning, so that it is likely that students will get satisfactory learning outcomes.

\section{CONCLUSION}

The data obtained from the results of the analysis carried out, then some conclusions can be drawn as follows. First, the boarding school environment has a significant positive effect on the learning outcomes of class XI IPS MA 1 Annuqayah Putri. This means that the better the boarding school environment is occupied by students, the higher the learning outcomes obtained by students. Conversely, the worse the boarding school environment is occupied by students, the lower the students' learning outcomes. Second, peers have a significant positive effect on class XI IPS MA 1 Annuqayah Putri's learning outcomes. This means that the better the peer influence, the higher the learning outcomes obtained by students, and conversely, the worse the peer influence, the lower the learning outcomes obtained by students. Third, the environment of Islamic boarding schools and peers has a significant positive effect on the learning outcomes of class XI IPS MA 1 Annuqayah Putri. This means that the better the boarding school environment and peer influence, the higher the learning outcomes obtained by students. Conversely, the worse the boarding school environment and peer influence, the lower the students' learning outcomes.

\section{AUTHORS 'CONTRIBUTIONS}

Mohammad Miftahusyai'an (lead researcher)

Yussi Rusdiana (research member)

Galih Puji Mulyoto (research member)

\section{ACKNOWLEDGMENTS}

Thank you to all lecturers of the State Islamic University of Malang Maulana Malik Ibrahim and friends who cannot be mentioned one by one.

\section{REFERENCES}

[1] A. Ahmadi and N. Uhbiyati, Science Education. Jakarta: PT Rineka Cipta, 1991.

[2] O. Hamalik, Teaching and Learning Process. Jakarta: Bumi Aksa, 2007.

[3] A. Munib and Et.all, Introduction to Education 
Science. Semarang: Uness Press, 2011.

[4] B. Maunah, Intellectual Tradition of Santri in Challenges and Barriers of Islamic Boarding School Education in the Future. Yogyakarta: Teras, 2009.

[5] O. Hasbullah, Autonomous education. Jakarta: PT Raja Grafindo Persada, 2006.

[6] Baharuddin, Development of Islamic education institutions towards professional and competitive management. Malang: UIN Press, 2011.

[7] Damsar, Introduction to Sociology. Jakarta: Kencana, 2011.

[8] A. Hadis, Psychology in Education. Bandung: Alfabeta, 2008.

[9] Z. Iskandar, Nvironmental Psychology (Theory and Concepts). Bandung: Refika Aditama, 2012.
[10] Y. \& Kurniawan and S. Ajat, "The role of peers in shaping the character of students at Madrasah Tsanawiyah,” J. Ilmu Sos., vol. 15, no. 2, 2010.

[11] Desmita, Developmental Psychology. Bandung: PT Remaja Rosdakarya, 2016.

[12] J. W. Santrock, . Psikologi pendidikan. : Jakarta: Kencana, 2008.

[13] J. Kurniawan, Z. M. Effendi, and S. Dwita, "The Effect of School Environment, Family Environment and Learning Motivation on Students' Learning Performance," Advances in Economics, Business and Management Research, 2018. https://www.atlantispress.com/proceedings/piceeba-18/25902637 (accessed Jul. 07, 2020). 